\title{
Agonist antibodies activating the Met receptor protect cardiomyoblasts from cobalt chloride-induced apoptosis and autophagy
}

\author{
S Gallo ${ }^{1,4}$, S Gatti ${ }^{1,4}$, V Sala ${ }^{1}$, R Albano ${ }^{2}$, P Costelli ${ }^{3}$, E Casanova ${ }^{2}$, PM Comoglio ${ }^{*, 1,2}$ and T Crepaldi ${ }^{*, 1}$
}

Met, the tyrosine kinase receptor for hepatocyte growth factor (HGF), mainly activates prosurvival pathways, including protection from apoptosis. In this work, we investigated the cardioprotective mechanisms of Met activation by agonist monoclonal antibodies (mAbs). Cobalt chloride $\left(\mathrm{CoCl}_{2}\right)$, a chemical mimetic of hypoxia, was used to induce cardiac damage in H9c2 cardiomyoblasts, which resulted in reduction of cell viability by (i) caspase-dependent apoptosis and (ii) - surprisingly autophagy. Blocking either apoptosis with the caspase inhibitor benzyloxycarbonyl-VAD-fluoromethylketone or autophagosome formation with 3-methyladenine prevented loss of cell viability, which suggests that both processes contribute to cardiomyoblast injury. Concomitant treatment with Met-activating antibodies or HGF prevented apoptosis and autophagy. Pro-autophagic Redd1, Bnip3 and phospho-AMPK proteins, which are known to promote autophagy through inactivation of the mTOR pathway, were induced by $\mathrm{CoCl}_{2}$. Mechanistically, Met agonist antibodies or HGF prevented the inhibition of mTOR and reduced the flux of autophagosome formation. Accordingly, their anti-autophagic function was completely blunted by Temsirolimus, a specific mTOR inhibitor. Targeted Met activation was successful also in the setting of low oxygen conditions, in which Met agonist antibodies or HGF demonstrated anti-apoptotic and anti-autophagic effects. Activation of the Met pathway is thus a promising novel therapeutic tool for ischaemic injury.

Cell Death and Disease (2014) 5, e1185; doi:10.1038/cddis.2014.155; published online 17 April 2014

Subject Category: Experimental Medicine

Hypoxia is critical in many pathological conditions including myocardial ischaemia. ${ }^{1}$ Cells respond to hypoxia by activation of the hypoxia-inducible factor HIF- $1 \alpha$, a transcription factor that modulates the expression of genes involved in angiogenesis, survival, metabolism and cell migration. ${ }^{2-4}$ In the normoxic state the HIF- $1 \alpha$ protein is hydroxylated, ubiquitinated and degraded in the proteasome. ${ }^{1}$ In the hypoxic state the activity of specific hydroxylases is quenched and HIF- $1 \alpha$ is stabilized..$^{5}$ It is known that cobalt, a transition metal, mimics hypoxia by causing inactivation of hydroxylase enzymes and stabilization of HIF- $1 \alpha .{ }^{6}$

Although the acute hypoxic response enhances cell survival and promotes adaptation to low oxygen environment, chronic or extreme hypoxic conditions initiate cell death program(s), among which apoptosis is the best known. ${ }^{7}$ Apoptosis is governed by a series of specialized proteins, functionally divided into pro-apoptotic (Bax) and anti-apoptotic (Bcl-2) molecules. ${ }^{8}$ Autophagy - that is, degradation of damaged proteins and intracellular organelles - is a less renowned regulator of cell viability. ${ }^{9}$ In the initial phase of stress conditions, autophagy exerts a protective function for cell survival. ${ }^{10}$ Chronic activation of autophagy - on the contrary results in enhanced cell death, through mechanism(s) that are not fully understood. ${ }^{11}$

Cardiomyocytes are sensitive to survival factors such as hepatocyte growth factor (HGF). ${ }^{12}$ The biological functions of HGF are mediated by a specific tyrosine kinase receptor, encoded by the MET proto-oncogene and by activation of multiple intracellular downstream signalling pathways. ${ }^{13}$ The HGF/Met axis is normally silent in terminally differentiated cardiomyocytes; however, it is induced and activated when the organ undergoes injury, including ischaemia. ${ }^{12,14}$ Moreover, it is known that Met is an inducible gene and that the promoter is activated by five Hypoxia Response Elements sensitive to HIF- $1 \alpha^{4}$ It has been proposed that HGF may be cardioprotective, attenuating ischaemia/reperfusion injury. ${ }^{15}$ Agonist monoclonal antibodies (mAbs) directed against the cell surface Met receptor stimulate receptor homodimerization, autophosphorylation and consequently kinase activation through their divalent nature. ${ }^{16,17}$ In the present study, we show that such antibodies vicariate HGF in protecting cardiac muscle cells from hypoxic injury. Unexpectedly, their prosurvival role is

\footnotetext{
${ }^{1}$ Department of Oncology, University of Turin, Turin, Italy; ${ }^{2}$ Candiolo Cancer Institute, FPO-IRCCS, Candiolo, Italy and ${ }^{3}$ Department of Clinical and Biological Sciences, University of Turin, Turin, Italy

*Corresponding author: PM Comoglio, Candiolo Cancer Institute, FPO-IRCCS, Street Provinciale 142, km 3.95, Candiolo 10060, Italy. Tel: + 390119933601 ; Fax: + 39011962 1525; E-mail: pcomoglio@ gmail.com or T Crepaldi, Institute of Anatomy, Corso Massimo d'Azeglio 52, Turin 10126, Italy. Tel: + 390116707773 ; Fax: + 39011236 7773; E-mail: tiziana.crepaldi@unito.it

${ }^{4}$ These authors contributed equally to this work.

Keywords: HGF receptor; hypoxia; apoptosis; autophagy; mTOR

Abbreviations: Baf, Bafylomicin A1; $\mathrm{CoCl}_{2}$, cobalt chloride; HGF, hepatocyte growth factor; LC3, microtubule-associated protein light chain 3; mAbs, monoclonal antibodies; MTT assay, 3-(4,5-dimethyl-2-thiazolyl)-2,5-diphenyl-2H-tetrazolium bromide assay; PHA, PHA-665752; Tem, Temsirolimus; zVAD (zVAD fmk), benzyloxycarbonyl-VAD-fluoromethylketone; 3-MA, 3-methyladenine

Received 19.8.13; revised 05.3.14; accepted 06.3.14; Edited by GM Fimia
} 
mediated not only by the known anti-apoptotic activity but by protection from autophagic damage as well.

\section{Results}

Met agonist antibodies stimulate receptor phosphorylation, downstream signalling and biological response in cardiomyoblasts. To assess the role of Met in cardiac protection from hypoxia injury, we studied the H9c2 rat cardiomyoblasts. These cells express cardiac markers Connexin43 and Troponin-I (Supplementary Figure S1a). First, we demonstrated using flow cytometry that the endogenous Met receptor is present at the cell surface (Figure 1a). Moreover, immunofluorescence (IF) analysis showed that Met is localized both at the plasma membrane and intracellularly (Supplementary Figure S1b). Second, we stimulated the Met tyrosine kinase activity by using the HGF ligand or two mAbs, DN30 and DO24, which we previously showed to be partial and full agonist of the Met receptor, respectively. ${ }^{16}$ All three Met agonists induced phosphorylation of Met (Figure 1b), activation of its principal effector Gab1 (Figure 1b) and stimulation of the main signalling pathways downstream Met (that is, Akt, Erk and mTOR, data not shown). In a classical 'wound-healing' assay, treatment with either mAb induced cells to migrate and to cover the wounded area at an extent similar to that induced by HGF (Figure 1c). As a control, treatment with an irrelevant (anti-VSV-G) antibody had no effect on cell migration (Supplementary Figure S2a).

$\mathrm{CoCl}_{2}$ induces cardiomyoblast apoptosis. $\mathrm{CoCl}_{2}$ mimics the hypoxic/ischaemic condition and is a simple and validated in vitro tool to study the molecular mechanisms driven by hypoxia. ${ }^{18}$ Indeed, after $\mathrm{CoCl}_{2}$ treatment, HIF-1 $\alpha$ protein expression significantly increased, starting from $3 \mathrm{~h}$ (Supplementary Figure S3a), whereas mRNA level was super-induced at later time (starting from $12 \mathrm{~h}$; Supplementary Figure S3b). To further assess the involvement of $\mathrm{HIF}-1 \alpha$ in $\mathrm{CoCl}_{2}$ response, we analysed the expression of known typical HIF-1 $\alpha$ target genes, such as Glut1, CAXII, GAPDH and Met itself. ${ }^{4,19-21}$ In time course experiments, a significant increase in mRNA levels was observed at $3 \mathrm{~h}$ for Glut1 and at $12 \mathrm{~h}$ for CAXII and Met (Supplementary Figure S3c-e). Induction of GAPDH protein was detected at $24 \mathrm{~h}$ (Supplementary Figure S3f). To investigate the $\mathrm{CoCl}_{2}$ effect on cell viability, we performed the 3-(4,5-dimethyl-2-thiazolyl)-2,5-diphenyl-2H-tetrazolium bromide (MTT) assay. Cardiomyoblasts treated with $\mathrm{CoCl}_{2}$ showed a significant reduction in cell survival in a dose- and time-dependent manner (Figures $2 \mathrm{a}$ and b). Moreover, $\mathrm{CoCl}_{2}$ decreased prosurvival pathways (that is, Akt, Erk and mTOR), which are stimulated by HGF-activated Met receptor (Supplementary Figure S4). Consistently, $\mathrm{CoCl}_{2}$ treatment significantly impaired the signalling response to HGF survival factor (Supplementary Figure S4). As it is known that hypoxia produces cell death through mitochondrial membrane permeabilization, ${ }^{22}$ we analysed the apoptotic response. We found that treatment with $\mathrm{CoCl}_{2}$ leads to a significant increase in the number of pyknotic nuclei, as compared with untreated cells (Figure 2c); this apoptotic event was mediated by the caspase-dependent pathway of cell death, as it was affected by the specific inhibitor zVAD (Figure 2d). We also analysed the ratio between Bax and Bcl-2 protein levels, known to be crucial in caspase-mediated apoptosis. The treatment with $\mathrm{CoCl}_{2}$ increased the pro-apoptotic Bax and decreased the anti-apoptotic Bcl-2 at early (12h) and late $(48 \mathrm{~h})$ time points, resulting in a significant enhancement

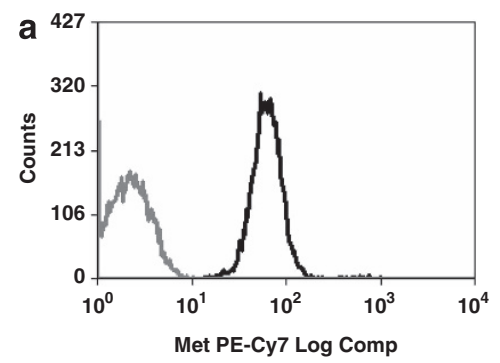

b
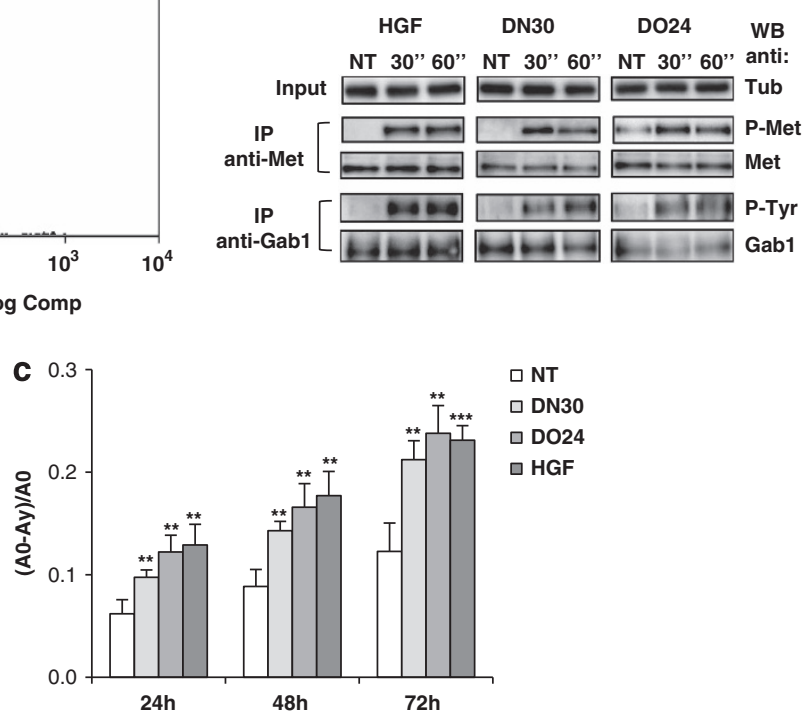

Figure $1 \mathrm{H} 9 \mathrm{c} 2$ cells express the Met receptor and are responsive to the treatment with Met agonists. (a) Flow cytometry detection of Met expression on cell surface. The $99.85 \%$ of viable cells showed a high immunofluorescence signal for the anti-HGF receptor antibodies. (b) Phosphorylation of Met and Gab1 is induced by HGF, DN30 and DO24. The cells were treated briefly ( $30^{\prime \prime}$ and $\left.60^{\prime \prime}\right)$ with $0.5 \mathrm{nM} \mathrm{HGF,} 100 \mathrm{nM}$ DN30 and DO24. Met and Gab1 IPs were analysed by WB with p-Met, Met and p-Tyr, Gab1 antibodies, respectively. Tubulin was used as loading control for the input lysates. (c) Wound-healing assay in cells treated or not (NT, white) for different lengths of time with DN30 (100 nM, light grey), DO24 (100 nM, middle grey) or HGF $(0.5 \mathrm{nM}$, dark grey). Values are the mean \pm S.D. of three independent experiments. $t$-test was calculated between treated samples versus NT control at each time point. ${ }^{* \star} P<0.01$ and ${ }^{* \star *} P<0.005$ 

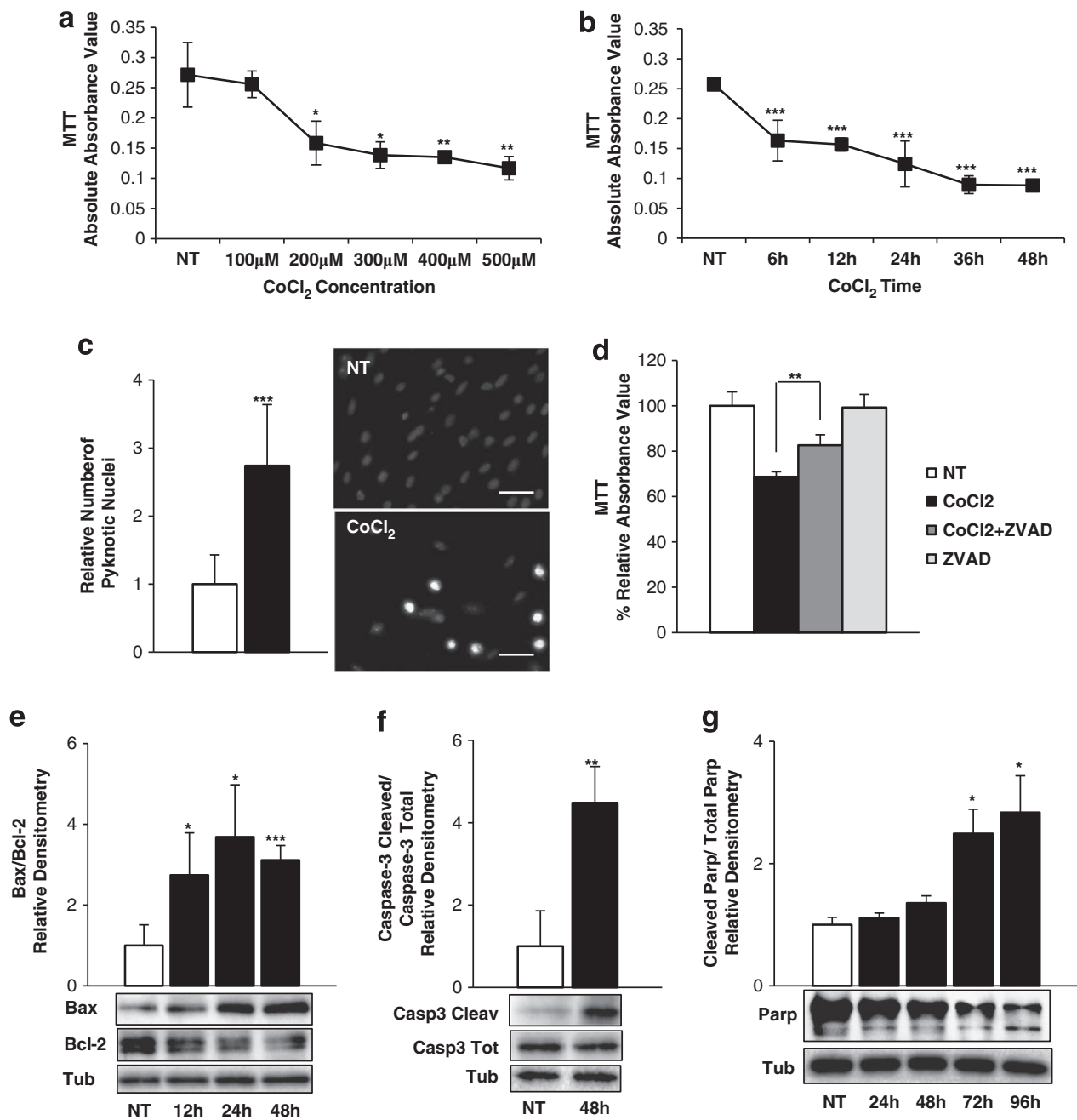

$\square$ NT

$\mathrm{CoCl}_{2}$

Figure $2 \mathrm{CoCl}_{2}$ induces apoptosis in $\mathrm{H} 9 \mathrm{c} 2$ cardiomyoblasts. Cell viability was evaluated through $\mathrm{MTT}$ analysis of (a) $\mathrm{CoCl}_{2}$ dose-dependent treatment for $24 \mathrm{~h}$ and (b) time-dependent treatment with $300 \mu \mathrm{M} \mathrm{CoCl}_{2}$. (c) Cells were untreated (NT, white) or treated with $300 \mu \mathrm{M} \mathrm{CoCl}_{2}$ (black) for $48 \mathrm{~h}$ and stained with DAPI. The percentage of pyknotic nuclei with respect to the total amount of nuclei was counted. Values are the mean \pm S.D. of 10 independent experiments and are expressed as fold relative to NT control. Representative images are shown on the right. Bar: $35 \mu \mathrm{m}$. (d) MTT was performed in NT cells (white), cells treated with $300 \mu \mathrm{M} \mathrm{CoCl}_{2}(\mathrm{black}), \mathrm{CoCl}_{2}+50 \mu \mathrm{M}$ zVAD caspase inhibitor (dark grey) and only zVAD (light grey) for $48 \mathrm{~h}$. Results are expressed as percentage of MTT reduction, relative to NT control. (e-g) Cells were treated with $300 \mu \mathrm{M} \mathrm{CoCl}$ and analysed for apoptotic markers in WB. The values show the ratio between the densitometric quantification of (e) Bax and Bcl-2, (f) cleaved and total caspase-3, (g) cleaved and total Parp bands and are expressed as fold relative to control. Representative images are shown below each graph. Tubulin was used as loading control. Values are the mean \pm S.D. of three independent experiments except for (c). For $t$-test, $\mathrm{CoCl}_{2}$-treated samples were compared with $\mathrm{NT}$ cells in all the experiments except for (d) where $\mathrm{CoCl}_{2}$ versus $\mathrm{CoCl}_{2}+\mathrm{zVAD}$ samples were compared. ${ }^{*} P<0.05,{ }^{* *} P<0.01$ and ${ }^{* \star *} P<0.005$

of $\mathrm{Bax} / \mathrm{Bcl}-2$ ratio (Figure $2 \mathrm{e}$ ). Consistent with the activation of the canonical mitochondrial pathway of apoptosis, the ratio between the cleaved and the total caspase-3 protein was significantly raised in cells treated for $48 \mathrm{~h}$ (Figure 2f). Finally, the ratio between cleaved and uncleaved PARP, one of the substrates of caspase-3, significantly increased at 72 and $96 \mathrm{~h}$ (Figure 2g).

Met agonist antibodies protect from $\mathrm{CoCl}_{2}$-induced apoptosis. To restore the prosurvival signalling and protect cardiomyoblasts from apoptosis, we concomitantly treated cells with $\mathrm{CoCl}_{2}$ and Met agonist antibodies or HGF. Met stimulation by either mAb or HGF fully prevented the loss of cell viability in the MTT assay (Figure 3a). The PHA-665752
(PHA), a specific inhibitor of the Met kinase, abolished the prosurvival activity of Met agonist antibodies and HGF; thus, protection was mediated specifically by the Met receptor (Figure 3a). We also demonstrated that the two mAbs, as well as $\mathrm{HGF}$, protected from $\mathrm{CoCl}_{2}$-induced reduction of cell number (Figure 3b). As a control the treatment with antiVSV-G antibody did not produce any effect (Supplementary Figure S2b and c). Importantly, DN30, DO24 and HGF prevented the $\mathrm{CoCl}_{2}$-induced rise in the number of pyknotic nuclei (Figure 3c). Accordingly, all above Met agonists prevented caspase-3 activation induced by $\mathrm{CoCl}_{2}$ (Figure $3 \mathrm{~d}$ ).

$\mathrm{CoCl}_{2}$ induces autophagy contributing to cardiomyoblast death. In our experiments, the apoptosis inhibitor zVAD 



c





Figure 3 Met agonist $\mathrm{mAbs}$ and $\mathrm{HGF}$ protect $\mathrm{H} 9 \mathrm{c} 2$ cardiomyoblasts from $\mathrm{CoCl}_{2}$-induced apoptosis. Cells were untreated (NT, white) or treated with $300 \mu \mathrm{M} \mathrm{CoCl} 2$ (black), $\mathrm{CoCl}_{2}+\mathrm{DN} 30$ (light grey), $\mathrm{CoCl}_{2}+\mathrm{DO} 24$ (middle grey) and $\mathrm{CoCl}_{2}+\mathrm{HGF}$ (dark grey). MAbs ( $100 \mathrm{nM}$ ) and HGF (0.5 nM) were concomitantly added to CoCl $\mathrm{Cor}_{2} 4 \mathrm{~h}$ (a) or for $48 \mathrm{~h} \mathrm{(b-d).} \mathrm{Cell} \mathrm{viability} \mathrm{(a)} \mathrm{and} \mathrm{cell} \mathrm{count} \mathrm{(b)} \mathrm{were} \mathrm{measured.} \mathrm{In} \mathrm{a,} \mathrm{the} \mathrm{separated} \mathrm{columns} \mathrm{on} \mathrm{the} \mathrm{right} \mathrm{represent} \mathrm{cells} \mathrm{treated} \mathrm{with} \mathrm{CoCl}_{2}+$ each Met agonist in the presence of PHA Met inhibitor ( $500 \mathrm{nM})$. Results are expressed as the percentage of MTT or cell number reduction, relative to NT control. (c) The number of DAPI-stained pyknotic nuclei on the total amount of nuclei was counted. For all treatments, the mean \pm S.D. was obtained from 10 independent experiments. (d) Caspase-3 protein cleavage was analysed by WB. The values show the ratio between the densitometric quantification of cleaved and total caspase- 3 bands. Values are expressed as fold relative to NT control and representative images are shown below the graph. The mean \pm S.D. was calculated in three independent experiments, except for the DAPI stain (c). For $t$-test each group of samples was compared with the $\mathrm{CoCl}_{2}$-treated cells. ${ }^{*} P<0.05,{ }^{* \star} P<0.01$ and ${ }^{* \star \star} P<0.005$

failed to fully inhibit cell death (Figure 2d). This observation suggested that the caspase-dependent apoptosis only partially contributes to the loss of cell viability induced by $\mathrm{CoCl}_{2}$. It has been reported that prolonged stimulation of the HIF- $1 \alpha$ pathway produces excess autophagy, which may also result in cell death. ${ }^{23}$ Thus, we evaluated the induction of proautophagic mechanisms in cells treated for different lengths of time with $\mathrm{CoCl}_{2}$. We performed an mRNA expression analysis of Redd1 and Bnip3, known transcriptional targets of HIF- $1 \alpha,{ }^{24,25}$ which promote autophagy by inhibition of mTOR. ${ }^{26,27}$ Both genes were significantly induced by $\mathrm{CoCl}_{2}$ treatment starting from $12 \mathrm{~h}$ and were maintained at high levels for $48 \mathrm{~h}$ (Figures $4 \mathrm{a}$ and b). Redd1 and Bnip3 protein levels were also increased in presence of $\mathrm{CoCl}_{2}$ (Figures $4 \mathrm{C}$ and d). Another HIF- $1 \alpha$-dependent mechanism of autophagy induction is mediated by AMPK phosphorylation and activation. ${ }^{28}$ We found that $\mathrm{CoCl}_{2}$ treatment induced a significant increase in AMPK phosphorylation, relative to untreated cells (Figure $4 \mathrm{e}$ ). It is known that P-AMPK is also an inhibitory molecule of the mTOR pathway; ${ }^{29}$ thus, we analysed the phosporylation state of p70S6K and 4EBP1, the two main substrates of mTOR. Phosphorylation levels of both proteins were significantly decreased in a time-dependent manner by $\mathrm{CoCl}_{2}$ treatment, starting from $24 \mathrm{~h}$ (Figures $4 \mathrm{f}$ and $\mathrm{g}$ ). This result indicates that $\mathrm{CoCl}_{2}$ treatment induces the inhibition of the mTOR pathway. As negative regulation of mTOR 
$\mathrm{CoCl}_{2}$

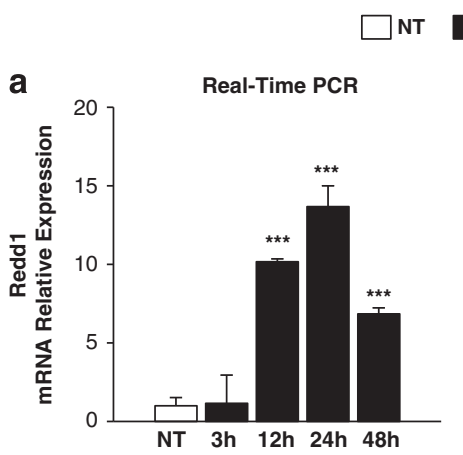

a



c

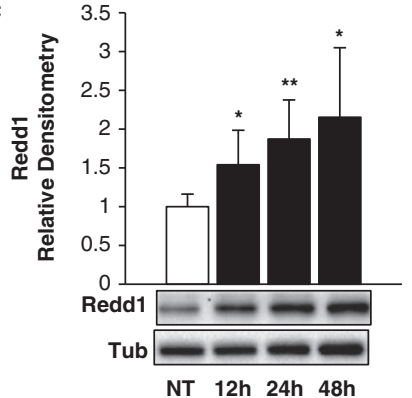

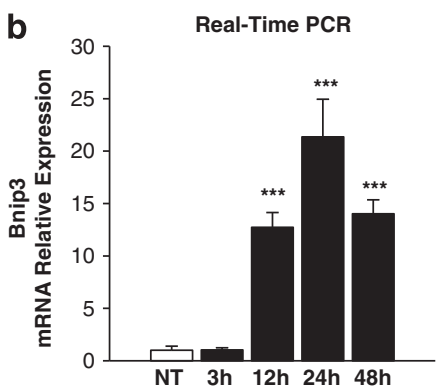

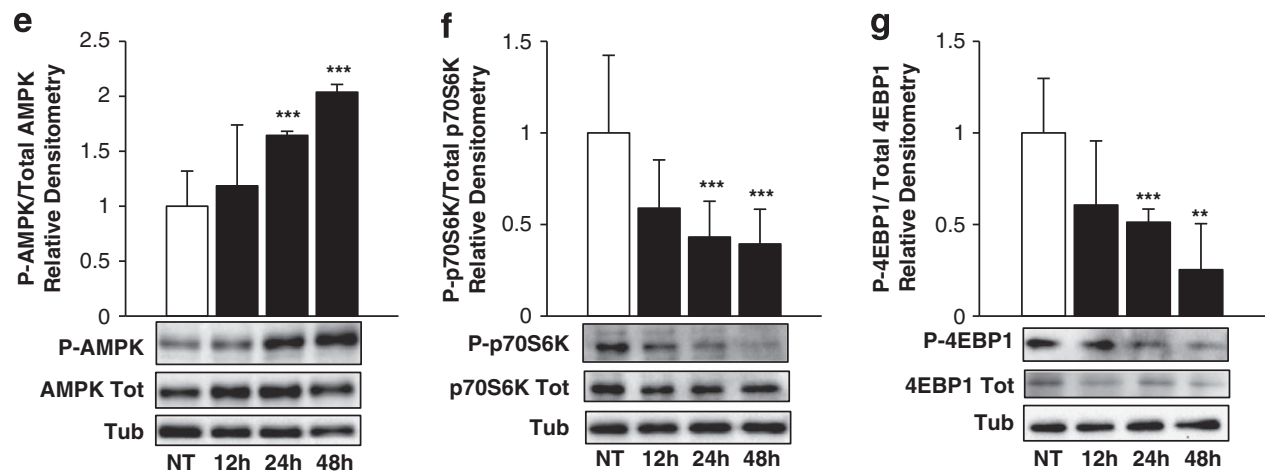

Figure $4 \mathrm{CoCl}_{2}$ induces negative regulation of the mTOR pathway in $\mathrm{H} 9 \mathrm{c} 2$ cardiomyoblasts. Cells were NT (white) or treated with $\mathrm{CoCl}_{2}(300 \mu \mathrm{M}$, black) for different lengths of time. Redd1 (a) and Bnip3 (b) mRNAs were analysed by real-time PCR (upper panels) and semi-quantitative RT-PCR (lower panels). $\beta$-actin mRNA was used as loading control. Densitometric quantification of Redd1 (c), Bnip3 (d), phospho-AMPK (e), phospho-p70S6K (f) and phospho-4EBP1 (g) protein levels were determined using WB. Representative images are shown below each graph and tubulin was used as loading control. In (e- $\mathbf{g})$ the values show the ratio between the densitometric quantification of phospho- and corresponding total bands. The values (mean \pm S.D.) were calculated in three independent experiments and are expressed as fold relative to NT. $t$-test was performed in treated samples versus NT. ${ }^{*} P<0.05,{ }^{* *} P<0.01$ and ${ }^{* * *} P<0.005$

signalling promotes autophagy ${ }^{30}$ we analysed some key proteins of different phases of autophagosome formation. Autophagy is positively regulated by Beclin-1, which binds the class III PI3K Vps34, thereby facilitating autophagosome formation. ${ }^{31}$ Another phase of autophagy is the elongation of the autophagosome, with generation of the lipidated form of LC3 called LC3II. $^{32}$ Finally, p62/SQSTM1 protein is an important marker of the autophagic machinery, as it recognizes ubiquitin and determines the cargo of ubiquitinated substrates in the autophagic-lysosomal pathway. ${ }^{33}$ Accordingly, we observed that both Beclin-1 and p62 protein levels were induced in $\mathrm{CoCl}_{2}$-treated cells (Figures $5 \mathrm{a}$ and $\mathrm{c}$ ) and that LC3 was processed from the inactive (LC3I) to the active form (LC3II, Figure 5b) in a time-dependent manner. In addition, the mRNAs of these autophagic proteins were induced in the presence of $\mathrm{CoCl}_{2}$ for $48 \mathrm{~h}$ (Figure $5 \mathrm{~d}$ ). Moreover, IF analysis revealed that $\mathrm{CoCl}_{2}$ induced LC3 puncta formation, proof of autophagosome maturation 
a

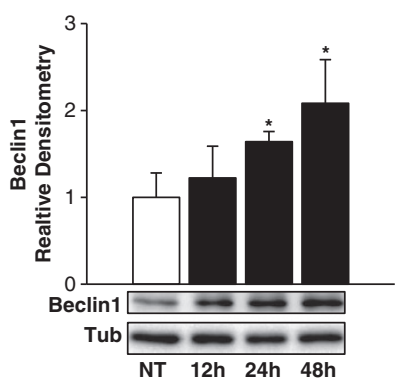

b

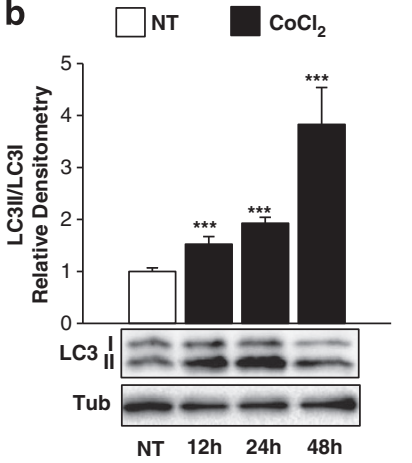

C

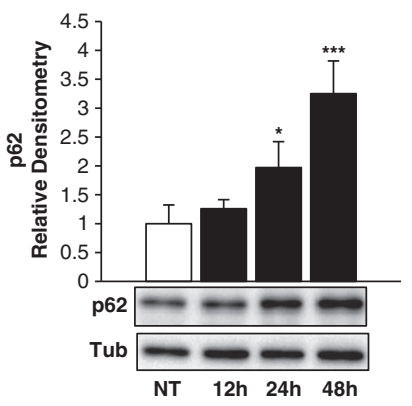

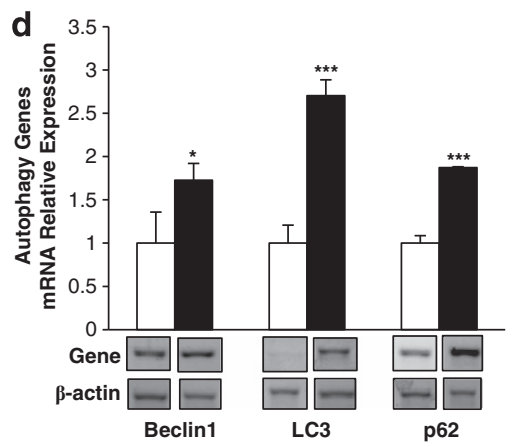

e
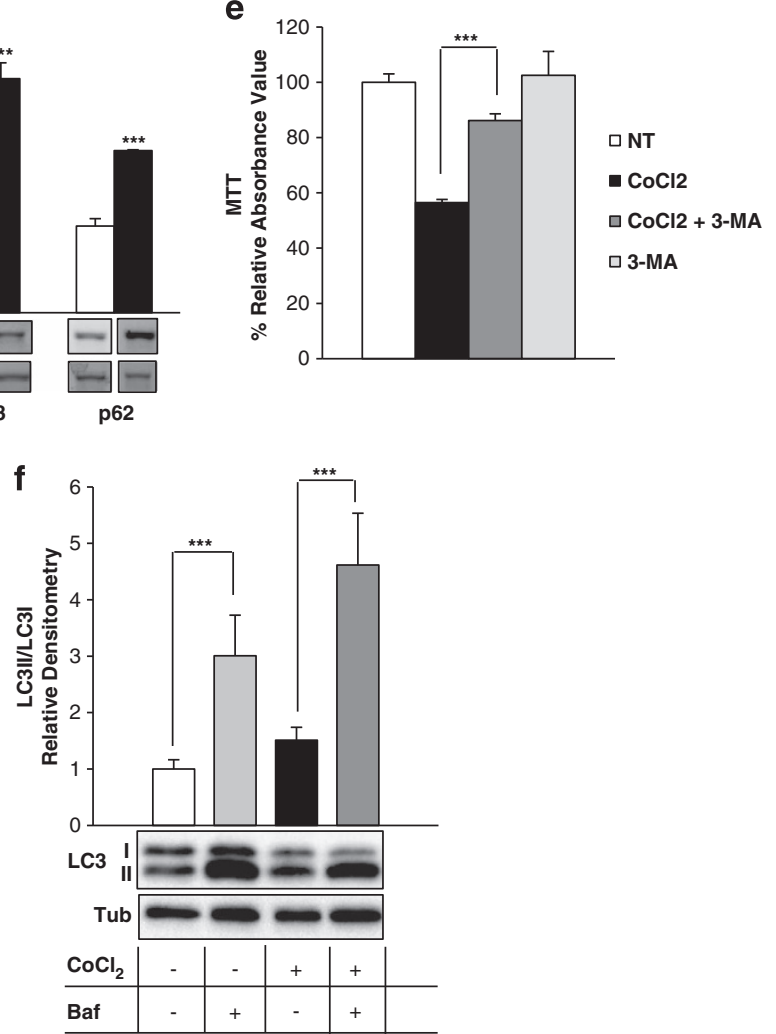

Figure $5 \mathrm{CoCl}_{2}$ induces autophagy in $\mathrm{H} 9 \mathrm{c} 2$ cardiomyoblasts. Cells were NT (white) or treated with $\mathrm{CoCl}_{2}(300 \mu \mathrm{M}$, black) for different lengths of time. Protein (a-c) and mRNAs (d) densitometric quantification of autophagic markers: Beclin-1, LC3 and p62. The densitometric quantification of protein LC3II/LC3I ratio is reported. mRNA expression analysis was performed at $48 \mathrm{~h}$. The t-test was performed on treated versus NT cells. (e) Cell viability was measured by MTT. Cells were NT (white) or treated with $\mathrm{CoCl}_{2}$ for $48 \mathrm{~h}$ (black), $\mathrm{CoCl}_{2}+1 \mathrm{mM}$ 3-MA inhibitor of autophagy in the last $12 \mathrm{~h}$ (dark grey) and 3-MA alone (light grey). Results are expressed as percentage of MTT reduction, relative to NT control. $t$-test was calculated comparing $\mathrm{CoCl}_{2}$ versus $\mathrm{CoCl}_{2}+3-\mathrm{MA}$. (f) Densitometric quantification of protein $\mathrm{LC} 3 \mathrm{II} / \mathrm{LC} 3 \mathrm{l}$ ratio in cells cultured in the presence or absence of $\mathrm{Baf}(50 \mathrm{nM})$. Cells were treated with $\mathrm{CoCl}_{2}$ for $48 \mathrm{~h}$ and Baf was added in the last $6 \mathrm{~h}$. In the graph four conditions of treatment are reported: $\mathrm{NT}$ (white), Baf (light grey), $\mathrm{CoCl}_{2}$ (black) and $\mathrm{CoCl}_{2}+\mathrm{Baf}$ (dark grey). $t$-test was calculated between NT versus Baf and $\mathrm{CoCl}_{2}$ versus $\mathrm{CoCl}_{2}+\mathrm{Baf}$. Tubulin and $\beta$-actin were used as loading control for protein and mRNA, respectively. Representative images are reported below each graph. The values are the mean \pm S.D. of three independent experiments. In all the experiments, except for (e), values are expressed as fold relative to NT. ${ }^{*} P<0.05$ and ${ }^{* * *} P<0.005$

(Supplementary Figure S5A and B). Finally, we asked whether increased autophagic response could participate into the $\mathrm{CoCl}_{2}$-induced loss of cell viability. We co-treated cardiomyoblasts with $\mathrm{CoCl}_{2}$ and 3-Methyladenine (3-MA), a selective inhibitor of the autophagic initiator PI3K type III. The inhibitor decreased the LC3 puncta formation (Supplementary Figure S5B and C) and, importantly, prevented the loss of cell viability and recovered as much as $80 \%$ of the basal value (Figure 5e). This last result indicates that, besides apoptosis, the autophagic process is involved in cell death induced by $\mathrm{CoCl}_{2}$. The increase in pro-autophagic proteins by hypoxic injury may be due to either enhanced formation or reduced degradation of autophagosomes. Treatment with bafilomycin A1 (Baf), an inhibitor of the vacuolar $\mathrm{H}^{+}$ ATPase of lysosomes, ${ }^{34}$ significantly increased the LC3II/LC3I ratio (Figure 5f), indicating a block on the basal lysosomaldependent degradation of the autophagosome cargo. H9c2 cells concomitantly treated with $\mathrm{CoCl}_{2}$ and Baf showed LC3II/LC3I protein levels and LC3 immunofluorescent puncta significantly higher than those observed in cells treated with 
$\mathrm{CoCl}_{2}$ alone (Figure $5 f$ and Supplementary Figure S5B and D). Altogether, these data suggest that $\mathrm{CoCl}_{2}$-induced death results from enhanced flux of autophagosome formation rather than from reduced clearance.

Met agonist antibodies protect from $\mathrm{CoCl}_{2}$-induced autophagy through the mTOR pathway. Treatment with DN30, DO24 or HGF prevented the increase of both LC3II/ $\mathrm{LC} 3 \mathrm{I}$ ratio and p62 protein levels (Figures $6 a$ and b). These results demonstrate that Met agonists inhibit the autophagy induced by $\mathrm{CoCl}_{2}$. To investigate the effect of HGF stimulation on the autophagic flux we again used the Baf inhibitor. In cell cultures exposed to Baf or Baf $+\mathrm{CoCl}_{2}$, the addition of HGF resulted in a significantly lower LC3II/LC3I ratio as compared with the corresponding treatment in the absence of the cytokine (Figure 6c). Lysosomal proteolysis was completely blocked by Baf; thus, an LC3II decrease below the Baf-induced levels indicates that HGF reduces the flux of autophagosome formation. The two Met agonist antibodies also decreased the LC3II/LC3I ratio in cells cultured in the presence of $\mathrm{CoCl}_{2}$ and Baf (Figure $6 \mathrm{~d}$ ). To identify the protective signalling involved in Met agonist action, we blocked the mTOR pathway known to be the main inhibitor of autophagy. In the presence of temsirolimus, a specific inhibitor of the mTOR complex, the Met agonist-mediated recovery of cell viability upon hypoxic injury was abrogated (Figure 7a). The level of mTOR activation in cultures exposed to $\mathrm{CoCl}_{2}$ in combination with Met agonists was higher than in cells treated with $\mathrm{CoCl}_{2}$ alone (Figures $7 \mathrm{~b}$ and c). In contrast, the Met agonist antibodies- or HGF-mediated mTOR activation was completely blunted by temsirolimus (Figures $7 \mathrm{~b}$ and $\mathrm{c}$ ). Accordingly, the Met agonist-mediated recovery of $\mathrm{LC} 3 \mathrm{II} / \mathrm{LC} 3 \mathrm{I}$ ratio from $\mathrm{CoCl}_{2}$-induced autophagy was reduced by mTOR pathway inhibition (Figure 7d). Altogether, these results indicate that mTOR activation has a key role in the Met-stimulated protection from autophagy.

Met agonist antibodies attenuate apoptosis and autophagy under hypoxic conditions. The cardioprotective action of the two Met agonist antibodies as well as HGF was evaluated under hypoxic environment at $1 \%$ of oxygen tension (Figure 8). First, we showed that hypoxic treatment produced reduction of cell viability (Figure $8 \mathrm{a}$ ), increase of pycnotic nuclei (Figure $8 \mathrm{~b}$ ) and induction of pro-autophagic proteins Redd1 and Bnip3 (Figure 8c). Next, we demonstrated that Met stimulation by the two mAbs as well as HGF under hypoxic conditions ameliorates cell viability (Figure $8 d$ ), reduces the number of pyknotic nuclei (Figure 8e)
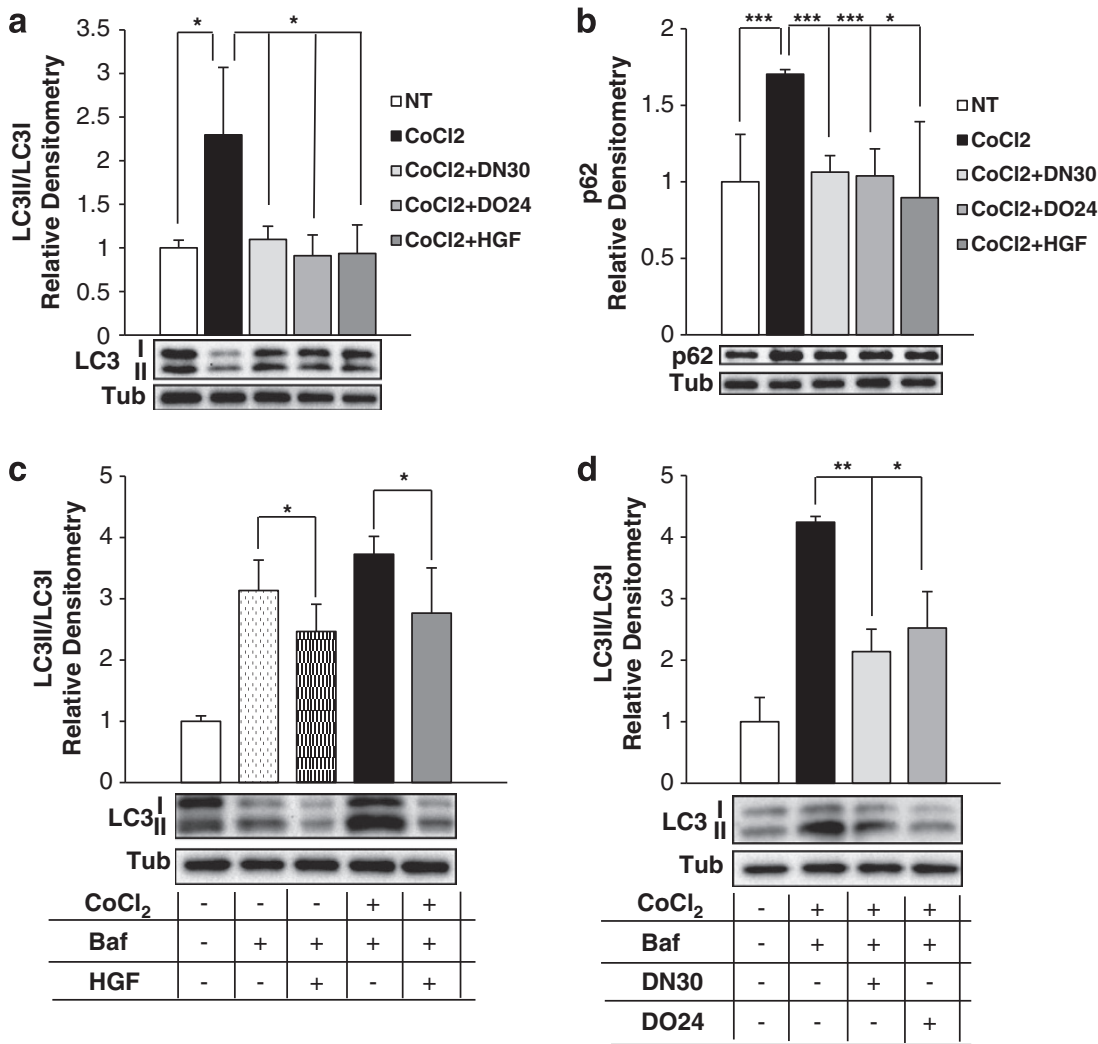

Figure 6 Met agonist antibodies and HGF protect H9c2 cardiomyoblasts from $\mathrm{CoCl}_{2}$-induced autophagy. (a and $\left.\mathbf{b}\right)$ Protein densitometric quantification of LC3II/LC3I ratio (a) and p62 (b), normalized on tubulin. Cells were NT (white) or treated with $300 \mu \mathrm{M} \mathrm{CoCl}_{2}$ (black), $\mathrm{CoCl}_{2}+\mathrm{DN} 30$ (100 nM, light grey), $\mathrm{CoCl}_{2}+\mathrm{DO} 4$ (100 nM, middle grey) and $\mathrm{CoCl}_{2}+\mathrm{HGF}\left(0.5 \mathrm{nM}\right.$, dark grey) for $48 \mathrm{~h}$. $t$-test was calculated for each treatment versus $\mathrm{CoCl}_{2}$. (c and d) Protein densitometric analysis of LC3II/LC3I ratio in NT cells (white (c and d)) or cells cultured in the presence of $50 \mathrm{nM}$ Baf (dotted light grey (c)), Baf $+\mathrm{HGF}\left(0.5 \mathrm{nM}\right.$, dotted dark grey (c)), Baf $+\mathrm{CoCl}_{2}(300 \mu \mathrm{M}$, black (c and d)), $\mathrm{Baf}+\mathrm{CoCl}_{2}+\mathrm{HGF}$ (dark grey (c)), Baf $+\mathrm{CoCl}_{2}+\mathrm{DN} 30\left(100 \mathrm{nM}\right.$, light grey (d)) and Baf $+\mathrm{CoCl}_{2}+\mathrm{DO} 24(100 \mathrm{nM}$, middle grey (d)). The cells were treated for $48 \mathrm{~h}$ and Baf was added in the last $6 \mathrm{~h}$. The values are the mean \pm S.D. of three independent experiments and are expressed as fold relative to NT. $t$-test was calculated for Baf versus Baf + HGF (c) and for $\mathrm{Baf}+\mathrm{CoCl}_{2}$ versus Baf $+\mathrm{CoCl}_{2}+$ Met agonists (c and $\mathbf{d}$ ). Representative images are reported below each graph. ${ }^{*} P<0.05,{ }^{* \star} P<0.01$ and ${ }^{* * *} P<0.005$ 

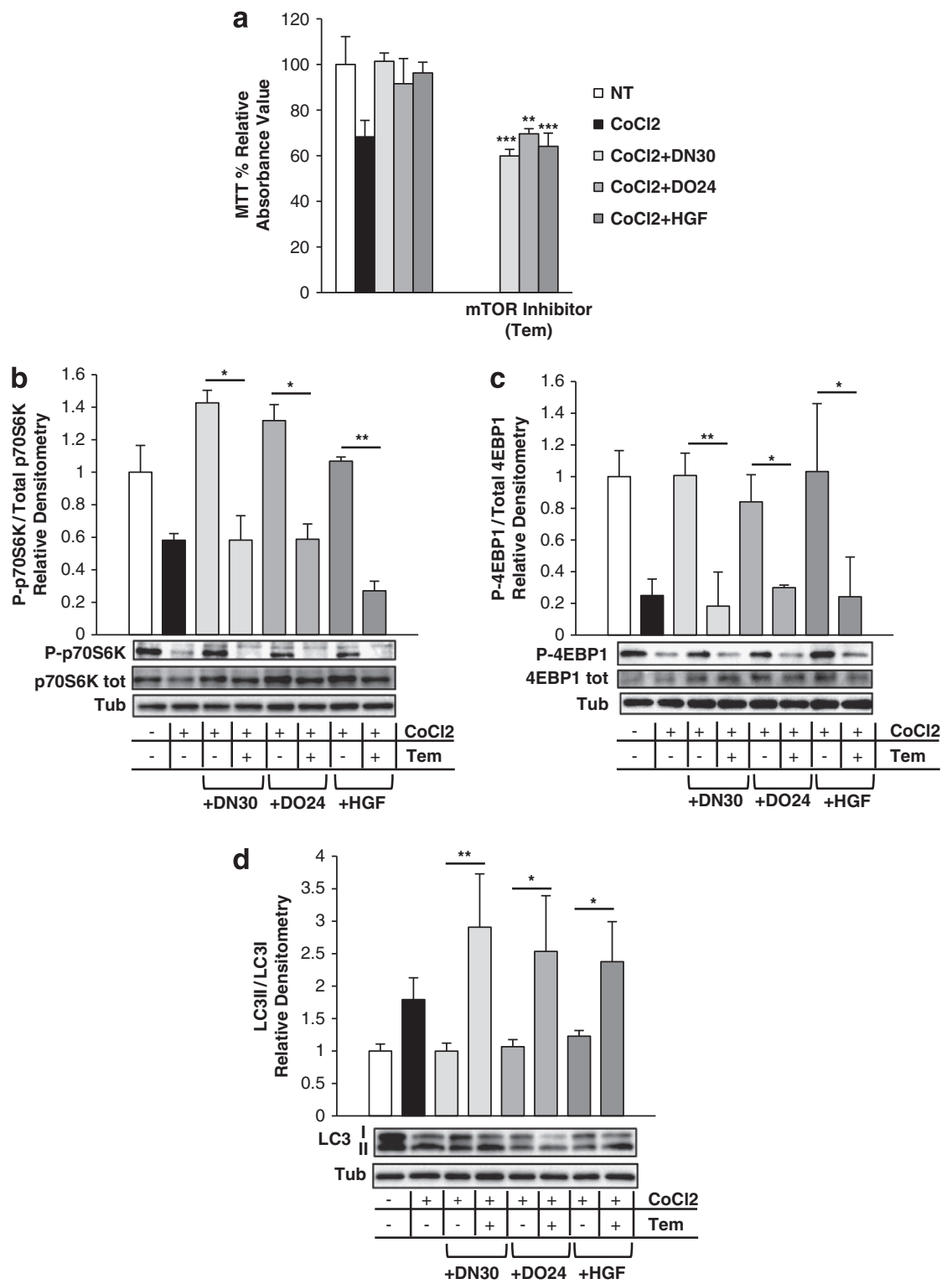

Figure 7 The anti-autophagic effect of Met agonists is mediated by the mTOR pathway. (a) MTT analysis in cardiomyoblast NT (white) or treated with $\mathrm{CoCl}_{2}$ ( $300 \mu \mathrm{M}$, black), $\mathrm{CoCl}_{2}+\mathrm{DN} 30$ (100 nM, light grey), $\mathrm{CoCl}_{2}+\mathrm{DO} 24$ (100 nM, middle grey) and $\mathrm{CoCl}_{2}+\mathrm{HGF}(0.5 \mathrm{nM}$, dark grey) for $24 \mathrm{~h}$ with or without the presence of Tem, the mTOR inhibitor $(1 \mu \mathrm{M})$. Results are expressed as percentage of MTT reduction, relative to NT control. The values are the mean \pm S.D. of three independent experiments. (b-d) Densitometric quantification of Phospho- and total p70S6K (b), phospho- and total 4EBP1 (c) and LC3II/LC3I ratio (d) by WB. Cells were NT (white) or treated with $300 \mu \mathrm{M} \mathrm{CoCl}$ (black), $\mathrm{CoCl}_{2}+\mathrm{DN} 30\left(100 \mathrm{nM}\right.$, light grey), $\mathrm{CoCl}_{2}+\mathrm{DO} 24\left(100 \mathrm{nM}\right.$, middle grey) and $\mathrm{CoCl}_{2}+\mathrm{HGF}(0.5 \mathrm{nM}$, dark grey) with or without Tem (1 $\mu \mathrm{M})$ for $48 \mathrm{~h}$. In $(\mathbf{b}$ and $\mathbf{c})$ the values show the ratio between the densitometric quantification of phospho and corresponding total bands. The values are the mean \pm S.D. of three independent experiments and are expressed as fold relative to NT. Tubulin was used as loading control. Representative images are reported below each graph. For $t$-test each group of treated samples in the presence of Tem was compared with corresponding group without Tem. ${ }^{*} P<0.05,{ }^{* *} P<0.01$ and ${ }^{* * *} P<0.005$

and decreases the level of autophagic ratio LC3II/LC3I and p62 (Figure 8f). In conclusion, these results show that Met agonists have anti-apoptotic and anti-autophagic effects also in low oxygen tension conditions.

\section{Discussion}

The effect of hypoxia in cardiomyocytes relies on duration and intensity of hypoxic stimulus. Short-term induction of HIF- $1 \alpha$ is beneficial, as the injured myocardium metabolically adapts to hypoxic condition. ${ }^{35}$ In contrast, long-term stabilization of
HIF- $1 \alpha$ may be detrimental. ${ }^{35-38}$ Accordingly, we found that sustained hypoxic injury is followed by cardiomyoblast grief.

It is known that HIF- $1 \alpha$ stabilization sensitizes tumour and neuronal cells to programmed cell death. ${ }^{39,22}$ The mechanisms at the basis of HIF- $1 \alpha$ apoptotic effect are not yet well understood but presumably involve Bnip $3{ }^{40} \mathrm{p} 53^{41}$ and increased production of ROS. ${ }^{42}$ All these processes converge on the activation of the intrinsic pathway of apoptosis. We found that treatment with $\mathrm{CoCl}_{2}$ induced a significant rise of pyknotic nuclei with concomitant increase in the $\mathrm{Bax} / \mathrm{Bcl}-2$ ratio followed by activation of caspase-3 cleavage. Blocking caspases 


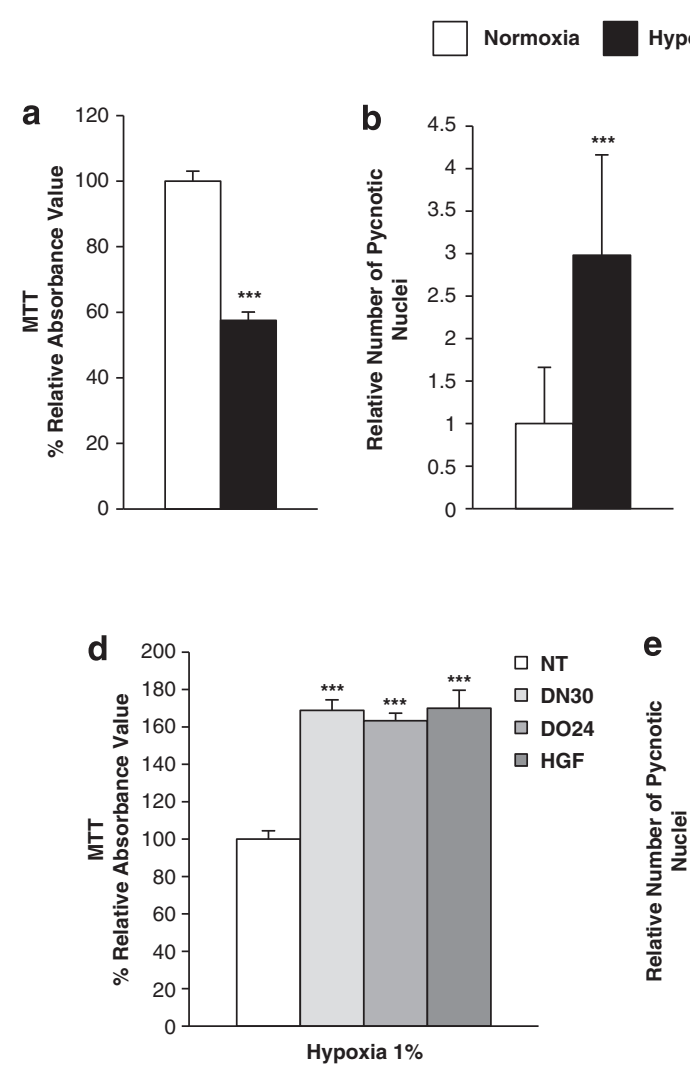

Hypoxia $1 \%$
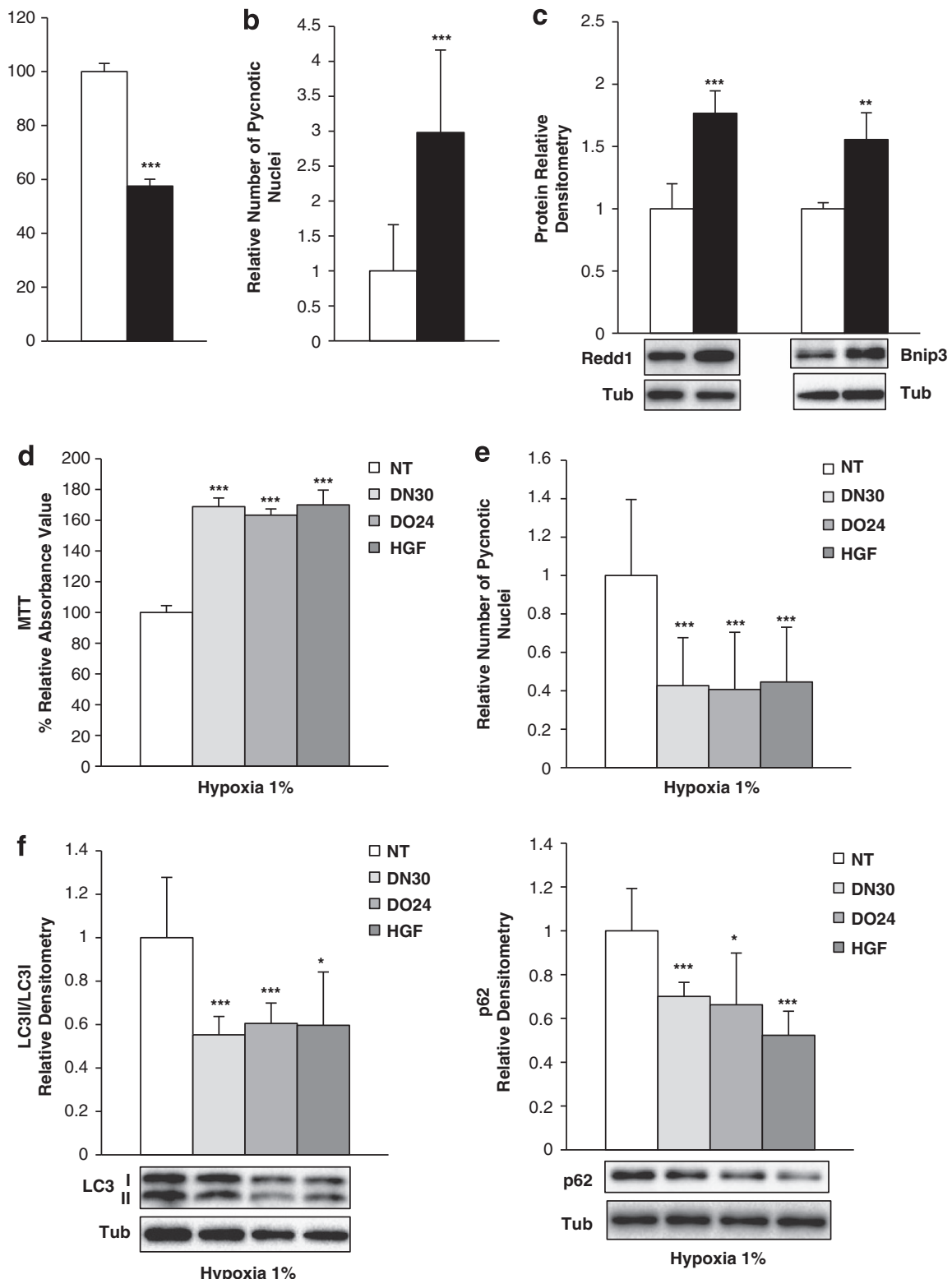

Figure 8 Met agonists protect H9c2 cardiomyoblasts from apoptosis and autophagy in low oxygen tension. (a-c) H9c2 cells were cultured in normoxic (white) or hypoxic (black) conditions for $48 \mathrm{~h}(\mathbf{a}$ and $\mathbf{b}$ ) or $72 \mathrm{~h}$ (c). (a) Cell viability was measured and results are expressed as the percentage of MTT reduction. (b) The number of DAPI-stained pyknotic nuclei on the total amount of nuclei was counted. (c) The pro-autophagic Redd1 and Bnip3 proteins were analysed using WB and the densitometric quantification was performed. (d-f) Cells cultured at low oxygen tension were untreated (NT, white) or treated with DN30 (light grey), DO24 (middle grey) and HGF (dark grey) for $48 \mathrm{~h}$ (d and e) or $96 \mathrm{~h}(\mathrm{f})$. MAbs $(100 \mathrm{nM})$ and HGF $(0.5 \mathrm{nM})$ were concomitantly added with the hypoxic culture. (d) MTT analysis was performed and results are expressed as percentage of cell viability increase. (e) Cells were stained for DAPI and the number of pyknotic nuclei on the total amount of nuclei was counted. (f) Protein densitometric quantification of LC3II/LC3I ratio and p62. The mean \pm S.D. was calculated in three independent experiments, except for DAPI stain where 10 independent experiments were performed. The values are expressed as fold relative to control. In WB the tubulin was used as loading control and representative images are shown below each graph. $t$-test was calculated between treated samples versus control. ${ }^{*} P<0.05,{ }^{* \star} P<0.01$ and ${ }^{* \star *} P<0.005$

through a chemical inhibitor significantly improved cell viability, validating the apoptotic pathway as a relevant factor in the $\mathrm{CoCl}_{2}$ hypoxic mimicking model.

Here we show that $\mathrm{CoCl}_{2}$-induced hypoxia - besides apoptosis - is also a strong inducer of autophagy. In fact, chemical hypoxia increases known markers of the autophagic-lysosomal pathway: Beclin-1 (an indicator of autophagy induction), conversion of LC3I to lipidated LC3II (an index of autophagosome abundance) and p62 (a marker of ubiquitinated substrate sequestration and degradation). ${ }^{31-33}$ Moreover, cell death induced by $\mathrm{CoCl}_{2}$ was blocked by 3-MA, an inhibitor of the class III PI3K Vps34, a canonical initiator of autophagy. The latter experiment indicates that autophagy causes uncontrolled 'self-cannibalism' in 
cardiomyoblasts and contributes to cell death. We also enlightened the cross-talk between apoptotic and autophagic pathways, as $\mathrm{CoCl}_{2}$ decreases $\mathrm{Bcl}-2$ and concomitantly induces Bnip3 and Beclin-1, known triggers of autophagy. In fact, it is reported in the literature that Beclin-1 is inhibited by $\mathrm{Bcl}-2^{43}$ and, in turn, Bcl-2 is associated with and inhibited by Bnip3. $^{44}$

The main regulator of autophagy is $\mathrm{mTOR}$, a potent sensor and integrator of signals stimulated by growth factors, nutrients and energy status. Under conditions of nutrient availability and normoxia, mTOR is active and phosphorylates ATG13, preventing its association with ULK and formation of the autophagosome. ${ }^{45}$ We found that both $\mathrm{CoCl}_{2}$ and real hypoxia promote upregulation of Bnip3 and Redd1, two different hypoxia-inducible target genes. It is known from the literature that these two proteins inhibit Rheb, a Ras-related small GTPase, and, as a consequence, lead to a negative regulation of mTOR. Bnip3 directly binds and inhibits Rheb, ${ }^{27}$ while Redd1 acts through a not-yet-defined mechanism involving TSC1/2, an inhibitor of Rheb. ${ }^{26}$ We also demonstrated that $\mathrm{CoCl}_{2}$ induces phosphorylation and activation of AMPK, another negative regulator of mTOR. ${ }^{29}$

HGF has been proposed as a cardioprotective factor. ${ }^{12,46-50}$ Patient administration of biologically active HGF may however be difficult as it is a large molecule containing a heparinbinding domain sequestered by low affinity-high avidity sites widespread among the extracellular matrix proteoglycans. ${ }^{51,52}$ Moreover, HGF is produced as an inactive precursor that has to be activated after cleavage by specific convertases. ${ }^{53}$ Compared with the natural HGF ligand, the $m A b s$ have a major advantage of being easier to be produced and more manageable for the therapeutic formulation. For agonist antibodies, their divalent nature is a benefit as they dimerize and activate the receptors. This property has been scrutinized in detail in the case of anti-Met antibodies in the effort of generating monovalent fully inhibitory Fabs, successfully employed in preclinical cancer therapy. ${ }^{17}$

Here we show that either HGF or the Met agonist antibodies DN30 and DO24 protect from caspase-dependent apoptosis as well as autophagy. The protection from autophagy is mediated by activation of mTOR. Consistently, the increase in phospho-p70S6K and phospho-4EBP1 levels and the inhibition of autophagic LC3 lipidation were abrogated by the mTOR inhibitor. It is likely that activation of mTOR is triggered by the PI3K/Akt pathway at different levels, such as the regulation of $\mathrm{mTOR} /$ Raptor complex or phosphorylation of TSC2. ${ }^{54,55}$ In addition, Erk inhibits the TSC1/2 complex. ${ }^{56}$

Met agonist antibodies represent a new important tool enriching the therapeutic arsenal to manage cardiac diseases. Apoptosis is harmful in the reperfusion phase of myocardial infarction. ${ }^{57}$ Furthermore, apoptosis is involved also in a wide spectrum of inherited cardiomyopathies, myocarditis, transplant rejection and heart failure. ${ }^{58}$ Met agonist antibodies prove to be effective in inhibiting autophagy as well, a less considered mechanism of cell damage in heart diseases. While several studies have reported that basal levels of autophagy are required for cardiac homoeostasis, ${ }^{59}$ induction of autophagic flux in response to ischaemia/ reperfusion insult is detrimental; ${ }^{11,60}$ thus, new tools against autophagic damage are desirable. This work provides a novel therapeutic approach to cardiac diseases that offers molecules displaying a dual mechanism of prosurvival activity.

\section{Materials and Methods}

Reagents. The rat cardiomyoblasts cell line $\mathrm{H} 9 \mathrm{c} 2$ was purchased from the American Type Culture Collection (ATCC, Manassas, VA, USA). The two Met agonist mAbs (DN30 and DO24) were produced by one of us (RA) from hybridomas obtained with the fusion between the immune spleen cells from Balb/c mice (Charles River Laboratories, Wilmington, MA, USA) immunized with GTL-16 cells, where the MET proto-oncogene is amplified and overexpressed, and the P3.X63.Ag8.653 myeloma cells. The purification and selection of the antibodies were performed as described in Prat et al. ${ }^{16} \mathrm{HGF}$ was acquired from Tebu-Bio (Le-Perray-en-Yvelines, FR), whereas $\mathrm{CoCl}_{2}$ and anti-VSV-G mAb were from Sigma (St. Louis, MO, USA). $\mathrm{CoCl}_{2}$ was dissolved in water. Met tyrosine kinase inhibitor PHA-665752 (PHA, $500 \mathrm{nM}$ ) was supplied by Pfizer (New York, NY, USA). mTor inhibitor Temsirolimus was used at $1 \mu \mathrm{M}$ and purchased from Sigma. The following inhibitors were purchased from Sigma: ZVAD (caspase inhibitor, $50 \mu \mathrm{M}$ ), 3-MA (inhibitor of class III PI3K Vps34, $1 \mathrm{mM}$ ) and Baf (inhibitor of the lysosomal vacuolar $\mathrm{H}^{+}$ATPase, $50 \mathrm{nM}$ ).

Cell culture and treatment. H9c2 cells were cultured in Dulbecco's modified Eagle's medium (DMEM, Sigma) supplemented with 10\% fetal bovine serum (FBS, Sigma), 1\% penicillin (Sigma), 1\% streptomycin (Sigma) and 1\% L-Glutamine (Sigma) and were incubated under $5 \% \mathrm{CO}_{2}$ at $37^{\circ} \mathrm{C}$. Cells were passed regularly and subcultured to $\sim 80 / 90 \%$ of confluence before all the experiments.

To mimic hypoxic conditions, the cell culture was starved with $0.5 \% \mathrm{FBS}$ and then treated with $\mathrm{CoCl}_{2}$ at various concentrations and for different lengths of time. In real hypoxia experiments, cells were cultured at low oxygen tension (1\%) in a HeraCell (AHSI, Bernareggio, MB, Italy) incubator. HGF $(0.5 \mathrm{nM})$ and the two Met agonist antibodies (DN30 and DO24, $100 \mathrm{nM}$ ) were administrated alone or concomitantly with the hypoxic treatment. The mAb against the VSV-G (100 or $300 \mathrm{nM}$ ) was used as control.

Immunoprecipitation (IP) and immunoblot (WB) analyses. Cells were lysed in two types of ice-cold lysis buffers: the not denaturant Dim Buffer for IP analysis and the RIPA Buffer for direct WB experiments, both added with protease inhibitor cocktail (Sigma). Cell lysates were subsequently sonicated and centrifuged at 14000 r.p.m. (20 min at $+4^{\circ} \mathrm{C}$ ). The protein concentration was evaluated through the Bio-Rad protein assay (Bio-Rad Laboratories, Hercules, CA, USA). For the IP analysis, $1.2 \mathrm{mg}$ of cell lysates were incubated overnight at $+4{ }^{\circ} \mathrm{C}$ with $5 \mu \mathrm{g}$ DN30 and DO24 for Met IP or with $5 \mu \mathrm{g}$ anti-Gab1 antibody (Millipore, Billerica, MA, USA) for Gab1 IP. Then, $20 \mu$ of protein G sepharose (GE-healthcare, Little Chalfont, BKM, UK) were added and incubated for $2 \mathrm{~h}$ at $+4{ }^{\circ} \mathrm{C}$. The WB and IP lysates were separated using SDS-PAGE and transferred to Hybond-P pvdf membrane (Amersham plc, Amersham, BKM, UK). After incubation in blocking solution (10\% bovine serum albumin, BSA, Sigma) at room temperature (RT), membranes were incubated overnight at $+4{ }^{\circ} \mathrm{C}$ with the primary antibodies (see Supplementary Table S1). Membranes were washed and then incubated with specific horseradish peroxidase-conjugated secondary antibodies (Amersham) for $1 \mathrm{~h}$ at RT. The proteins were revealed by enhanced chemiluminescence of the ECL Prime detection kit (GE-healthcare) and quantified with the Image Lab software (Bio-Rad Laboratories).

Analysis of cell death: MTT assay, DAPI stain and cell count. Cell viability was evaluated using the MTT quantitative colorimetric assay (Roche Applied Science, Indianapolis, IN, USA). The absorbance of the converted purple formazan crystals from the yellow solution was measured at $595 \mathrm{~nm}$.

Pyknosis was evaluated through DAPI stain. Cells, after washing with phosphatebuffered saline (PBS), were fixed with $95 \%$ ethanol for 10 min at RT. Staining with DAPI was performed for 30 min at $+37^{\circ} \mathrm{C}$. Then cells were washed with PBS and fluorescence was evaluated with the DMRI Leica inverted microscope. The percentage of pyknotic nuclei in the total number of nuclei was counted. For each treatment 10 independent evaluations were taken.

The cell count was performed in the burker chamber. We measured the number of cells in $1 \mathrm{ml}$ of DMEM.

Flow cytometric analysis. To observe Met expression on cellular surface, $\sim 2 \times 10^{5}$ cells, resuspended in $100 \mu$ l of PBS added with $1 \%$ FBS, were stained 
20 min at RT, in the dark, with DN30 and DO24 mAbs previously conjugated with PE-Cy7 fluorochrome (using Lightning-Link PE-Cy7 Tandem Conjugation Kit, Innova Biosciences, Cambridge, UK). After wash, samples were analysed on a CyAn ADP LX nine-color analyser (Beckman Coulter, Brea, CA, USA). Dead cells were eliminated by excluding DAPI-positive population.

Wound-healing assay. Cells were plated in 24-well plates and maintained in DMEM $10 \%$ FBS until confluence, and then were incubated in DMEM 0.5\% FBS for $18 \mathrm{~h}$. The monolayers were wounded with a plastic pipette and a cross between two lines was created. Then cells were washed with PBS and incubated for 24,48 and $72 \mathrm{~h}$ in medium with or without HGF, Met agonist mAbs or anti-VSV $\mathrm{G} \mathrm{mAb}$. Images of wound at the start moment and after the treatment were taken with DMRI Leica inverted microscope. Migration was quantified by evaluating the area of wound at time zero (A0) and at time after the treatment (Ay, $y=24 \mathrm{~h}, 48$ or $72 \mathrm{~h}$ ). Normalization and quantification on the basis of three independent experiments were obtained by the formula $(\mathrm{A} 0-\mathrm{Ay}) / \mathrm{A} 0$.

mRNA analysis: semi-quantitative reverse-transcription PCR and real-time PCR. Total RNA was extracted with Trizol reagent, following the manufacturer's protocol (Invitrogen, Carlsbad, CA, USA). Then RNA was quantified with the NanoDrop ND-1000 and the reverse transcription was performed using High Capacity cDNA Reverse Transcription Kit according to the manufacturer's recommendation (Applied Biosystem, Foster City, CA, USA). The cDNA was used for real-time PCR analysis using the SsoFast EvaGreen supermix and the MiniOpticon Thermal Cycler (Bio-Rad Laboratories) and for semi-quantitative RT-PCR using various primers (see Supplementary Table S2). Control samples were prepared without adding the RT enzyme to the reaction, and $\beta$-actin was used as control.

IF analysis. Cells plated in 24-well plates were fixed with ice-cold $4 \%$ paraformaldehyde (PAF, Sigma) dissolved in PBS for $10 \mathrm{~min}$ and then washed with PBS. In all the experiments, except for the membrane fluorescence of Supplementary Figure $\mathrm{S} 1 \mathrm{~b}$, left panel, the fixed cells were permeabilized with $0.1 \%$ Triton X-100 (Sigma). Then the cells were saturated with BSA (1\%, Sigma) and incubated with the primary antibody (See Supplementary Table S1) for $1 \mathrm{~h}$ at RT. Secondary antibody incubation was performed with the Alexa Fluor 488conjugated goat anti-mouse or anti-rabbit antibody or with the Alexa Fluor 546-conjugated goat anti-mouse antibody (Molecular Probes/Invitrogen) for $1 \mathrm{~h}$ at RT. DAPI was added at the end of secondary antibody incubation for $5 \mathrm{~min}$ at RT. Images were taken through the DMRE Leica fluorescence microscope and processed with LAS AF software (Leica Microsystems, Wetzlar, Germany).

Statistical analysis. All data are expressed as the mean \pm S.D. The significant difference between the means taken from different samples was analysed through independent two-tailed $t$-tests. $P$-value $<0.05$ was considered statistically significant. For experimental details see each figure legend.

\section{Conflict of Interest}

The authors declare no conflict of interest.

Acknowledgements. We gratefully acknowledge the technical support of Costanzo Costamagna (hypoxic incubator) and Fabrizio Pin (Real-Time PCR). This work was supported by grants from the Association Française contre les Myopathies (AFM no. 15816) to TC and from AIRC to PMC (IG no. 11852) and to PC (IG no. 9153). Fellowship of VS was provided by FP7-2010-ICT-GC "EMSAFETY" project no. 265772.

1. Semenza GL. Hypoxia-inducible factors in physiology and medicine. Cell 2012; 148 399-408.

2. Goldberg MA, Schneider TJ. Similarities between the oxygen-sensing mechanisms regulating the expression of vascular endothelial growth-factor and erythropoietin. $J$ Biol Chem 1994; 269: 4355-4359

3. Semenza GL, Roth PH, Fang HM, Wang GL. Transcriptional regulation of genes encoding glycolytic-enzymes by hypoxia-inducible factor-1. J Biol Chem 1994; 269: 23757-23763.

4. Pennacchietti S, Michieli P, Galluzzo M, Mazzone M, Giordano S, Comoglio PM. Hypoxia promotes invasive growth by transcriptional activation of the met protooncogene. Cance Cell 2003; 3: 347-361.
5. Aragones J, Fraisl $P$, Baes $M$, Carmeliet $P$. Oxygen sensors at the crossroad of metabolism. Cell Metab 2009; 9: 11-22.

6. Epstein ACR, Gleadle JM, McNeill LA, Hewitson KS, O'Rourke J, Mole DR et al. C-elegans EGL-9 and mammalian homologs define a family of dioxygenases that regulate HIF by prolyl hydroxylation. Cell 2001; 107: 43-54

7. Piret JP, Mottet D, Raes M, Michiels C. Is HIF-1 alpha a pro- or an anti-apoptotic protein? Biochem Pharmacol 2002; 64: 889-892.

8. Adams JM, Cory S. The Bcl-2 protein family: arbiters of cell survival. Science 1998; 281: 1322-1326.

9. Mizushima N, Levine B, Cuervo AM, Klionsky DJ. Autophagy fights disease through cellular self-digestion. Nature 2008; 451: 1069-1075.

10. Rabinowitz JD, White E. Autophagy and metabolism. Science 2010; 330: 1344-1348.

11. Matsui $Y$, Takagi $H, Q u$ XP, Abdellatif M, Sakoda H, Asano $T$ et al. Distinct roles of autophagy in the heart during ischaemia and reperfusion - roles of AMP-activated protein kinase and Beclin 1 in mediating autophagy. Circ Res 2007; 100: 914-922.

12. Nakamura T, Mizuno S, Matsumoto K, Sawa $Y$, Matsuda H, Nakamura T. Myocardial protection from ischaemia/reperfusion injury by endogenous and exogenous HGF. J Clin Invest 2000; 106: 1511-1519.

13. Trusolino L, Bertotti A, Comoglio PM. MET signaling: principles and functions in development, organ regeneration and cancer. Nat Rev Mol Cell Biol 2010; 11: 834-848.

14. Riess I, Sala V, Leo C, Demaria M, Gatti S, Gallo S et al. A mouse model for spatial and temporal expression of HGF in the heart. Transgenic Res 2011; 20: 1203-1216.

15. Sala V, Crepaldi T. Novel therapy for myocardial infarction: can HGF/Met be beneficial? Cell Mol Life Sci 2011; 68: 1703-1717.

16. Prat M, Crepaldi T, Pennacchietti S, Bussolino F, Comoglio PM. Agonistic monoclonal antibodies against the Met receptor dissect the biological responses to HGF. J Cell Sci 1998; 111: 237-247.

17. Pacchiana G, Chiriaco C, Stella MC, Petronzelli F, De Santis R, Galluzzo M et al. Monovalency unleashes the full therapeutic potential of the DN-30 anti-Met antibody. J Biol Chem 2010; 285: 36149-36157.

18. Goldberg MA, Dunning SP, Bunn HF. Regulation of the erythropoietin gene - evidence that the oxygen sensor is a heme protein. Science 1988; 242: 1412-1415

19. Ebert BL, Firth JD, Ratcliffe PJ. Hypoxia and mitochondrial inhibitors regulate expression of glucose transporter-1 via distinct cis-acting sequences. J Biol Chem 1995; 270 : 29083-29089.

20. Wykoff CC, Beasley NJP, Watson PH, Turner KJ, Pastorek J, Sibtain A et al. Hypoxiainducible expression of tumor-associated carbonic anhydrases. Cancer Res 2000; 60: 7075-7083.

21. Graven KK, Yu Q, Pan D, Roncarati JS, Farber HW. Identification of an oxygen responsive enhancer element in the glyceraldehyde-3-phosphate dehydrogenase gene. Biochim Biophys Acta 1999; 1447: 208-218.

22. Jung JY, Kim WJ. Involvement of mitochondrial- and Fas-mediated dual mechanism in CoCl2-induced apoptosis of rat PC12 cells. Neurosci Lett 2004; 371: 85-90.

23. Gustafsson $A B$, Gottlieb RA. Recycle or die: the role of autophagy in cardioprotection J Mol Cell Cardiol 2008; 44: 654-661.

24. Shoshani T, Faerman A, Mett I, Zelin E, Tenne T, Gorodin S et al. Identification of a novel hypoxia-inducible factor 1-responsive gene, RTP801, involved in apoptosis. Mol Cell Biol 2002; 22: 2283-2293.

25. Bellot G, Garcia-Medina R, Gounon P, Chiche J, Roux D, Pouyssegur J et al. Hypoxiainduced autophagy is mediated through hypoxia-inducible factor induction of BNIP3 and BNIP3L via their BH3 domains. Mol Cell Biol 2009; 29: 2570-2581.

26. Brugarolas J, Lei K, Hurley RL, Manning BD, Reiling JH, Hafen E et al. Regulation of mTOR function in response to hypoxia by REDD1 and the TSC1/TSC2 tumor suppressor complex. Gene Dev 2004; 18: 2893-2904.

27. Li Y, Wang Y, Kim EJ, Beemiller P, Wang CY, Swanson J et al. Bnip3 mediates the hypoxia-induced inhibition on mammalian target of rapamycin by interacting with rheb. J Biol Chem 2007: 282: 35803-35813.

28. Bohensky J, Leshinsky S, Srinivas V, Shapiro IM. Chondrocyte autophagy is stimulated by HIF-1 dependent AMPK activation and mTOR suppression. Pediatr Nephrol 2010; 25: 633-642.

29. Shaw RJ, Bardeesy N, Manning BD, Lopez L, Kasmatka M, DePinho RA et al. The LKB1 tumor suppressor negatively regulates mTOR signaling. Cancer Cell 2004; 6: 91-99.

30. Meijer AJ, Codogno P. Regulation and role of autophagy in mammalian cells. Int J Biochem Cell B 2004; 36: 2445-2462

31. Furuya N, Yu F, Byfield M, Pattingre S, Levine B. The evolutionarily conserved domain of Beclin 1 is required for Vps34 binding, autophagy and tumor suppressor function. Autophagy 2005; 1: 46-52.

32. Weidberg H, Shvets E, Shpilka T, Shimron F, Shinder V, Elazar Z. LC3 and GATE-16/ GABARAP subfamilies are both essential yet act differently in autophagosome biogenesis. EMBO J 2010; 29: 1792-1802.

33. Bjorkoy G, Lamark T, Johansen T. p62/SQSTM1 - a missing link between protein aggregates and the autophagy machinery. Autophagy 2006; 2: 138-139.

34. Yamamoto A, Tagawa Y, Yoshimori T, Moriyama Y, Masaki R, Tashiro Y et al. Bafilomycin A(1) prevents maturation of autophagic vacuoles by inhibiting fusion between autophagosomes and lysosomes in rat hepatoma cell line, H-4-II-E cells. Cell Struct Funct 1998; 23: 33-42.

35. Hashmi S, Al Salam S. Hypoxia-inducible factor-1 alpha in the heart a double agent? Cardiol Rev 2012; 20: 268-273. 
36. Granger A, Abdullah I, Huebner F, Stout A, Wang T, Huebner T et al. Histone deacetylase inhibition reduces myocardial ischaemia-reperfusion injury in mice. FASEB $J$ 2008; 22: 3549-3560.

37. Holscher M, Schafer K, Krull S, Farhat K, Hesse A, Silter $M$ et al. Unfavourable consequences of chronic cardiac HIF-1 stabilization. Cardiovasc Res 2012; 94: 77-86.

38. Lei L, Mason S, Liu DG, Huang Y, Marks C, Hickey R et al. Hypoxia-inducible factor-dependent degeneration, failure, and malignant transformation of the heart in the absence of the von Hippel-Lindau protein. Mol Cell Biol 2008; 28: 3790-3803.

39. Moeller BJ, Dreher MR, Rabbani ZN, Schroeder T, Cao YT, Li CY et al. Pleiotropic effects of HIF-1 blockade on tumor radiosensitivity. Cancer Cell 2005; 8: 99-110.

40. Sowter HM, Ratcliffe PJ, Watson P, Greenberg AH, Harris AL. HIF-1-dependent regulation of hypoxic induction of the cell death factors BNIP3 and NIX in human tumors. Cancer Res 2001; 61: 6669-6673.

41. An WG, Kanekal M, Simon MC, Maltepe E, Blagosklonny MV, Neckers LM. Stabilization of wild-type p53 by hypoxia-inducible factor 1 alpha. Nature 1998; 392: 405-408.

42. Ciafre SA, Niola F, Giorda E, Farace MG, Caporossi D. CoCl2-simulated hypoxia in skeletal muscle cell lines: role of free radicals in gene up-regulation and induction of apoptosis. Free Radic Res 2007; 41: 391-401.

43. Pattingre S, Tassa A, Qu XP, Garuti R, Liang XH, Mizushima N et al. Bcl-2 antiapoptotic proteins inhibit Beclin 1-dependent autophagy. Cell 2005; 122: 927-939.

44. Imazu T, Shimizu S, Tagami S, Matsushima M, Nakamura Y, Miki T et al. Bcl-2/E1B $19 \mathrm{kDa}$-interacting protein 3-like protein (Bnip3L) interacts with $\mathrm{Bcl}-2 / \mathrm{Bcl}-\mathrm{x}(\mathrm{L})$ and induces apoptosis by altering mitochondrial membrane permeability. Oncogene 1999; 18: 4523-4529.

45. Jung $\mathrm{CH}$, Jun $\mathrm{CB}$, Ro SH, Kim YM, Otto NM, Cao J et al. ULK-Atg13-FIP200 complexes mediate mTOR signaling to the autophagy machinery. Mol Biol Cell 2009; 20 : 1992-2003.

46. Chen XH, Minatoguchi S, Kosai K, Yuge K, Takahashi T, Arai M et al. In vivo hepatocyte growth factor gene transfer reduces myocardial ischaemia-reperfusion injury through its multiple actions. J Card Fail 2007; 13: 874-883.

47. Pietronave S, Forte G, Locarno D, Merlin S, Zamperone A, Nicotra G et al. Agonist monoclonal antibodies against HGF receptor protect cardiac muscle cells from apoptosis. Am J Physiol Heart Circ Physiol 2010; 298: H1155-H1165.

48. Urbanek K, Rota M, Cascapera S, Bearzi C, Nascimbene A, De Angelis A et al. Cardiac stem cells possess growth factor-receptor systems that after activation regenerate the infarcted myocardium, improving ventricular function and long-term survival. Circ Res 2005; 97: 663-673.

49. Kitta K, Day RM, Ikeda T, Suzuki YJ. Hepatocyte growth factor protects cardiac myocytes against oxidative stress-induced apoptosis. Free Radic Biol Med 2001; 31: 902-910.

50. Iwasaki M, Adachi Y, Nishiue T, Minamino K, Suzuki Y, Zhang Y et al. Hepatocyte growth factor delivered by ultrasound-mediated destruction of microbubbles induces proliferation of cardio-myocytes and amelioration of left ventricular contractile function in doxorubicininduced cardiomyopathy. Stem Cells 2005; 23: 1589-1597.

51. Jiang WG, Martin TA, Parr C, Davies G, Matsumoto K, Nakamura T. Hepatocyte growth factor, its receptor, and their potential value in cancer therapies. Crit Rev Oncol Hematol 2005; 53: 35-69.

52. Kemp LE, Mulloy B, Gherardi E. Signaling by HGF/SF and Met: the role of heparan sulphate co-receptors. Biochem Soc Trans 2006; 34: 414-417.

53. Naldini L, Tamagnone L, Vigna E, Sachs M, Hartmann G, Birchmeier W et al. Extracellular proteolytic cleavage by urokinase is required for activation of hepatocyte growth-factor scatter factor. EMBO J 1992; 11: 4825-4833.

54. Vander Haar E, Lee SI, Bandhakavi S, Griffin TJ, Kim DH. Insulin signaling to mTOR mediated by the Akt/PKB substrate PRAS40. Nat Cell Biol 2007; 9: 316-323.

55. Inoki K, Li Y, Zhu T, Wu J, Guan KL. TSC2 is phosphorylated and inhibited by Akt and suppresses mTOR signaling. Nat Cell Biol 2002; 4: 648-657.

56. Ma L, Chen ZB, Erdjument-Bromage H, Tempst P, Pandolfi PP. Phosphorylation and functional inactivation of TSC2 by Erk: implications for tuberous sclerosis and cancer pathogenesis. Cell 2005; 121: 179-193.

57. Kang PM, Haunstetter A, Aoki H, Usheva A, Izumo S. Morphological and molecular characterization of adult cardiomyocyte apoptosis during hypoxia and reoxygenation. Circ Res 2000; 87: 118-125.

58. Gill C, Mestril R, Samali A. Losing heart: the role of apoptosis in heart disease - a novel therapeutic target? FASEB J 2002; 16: 135-146.

59. Whelan RS, Kaplinskiy V, Kitsis RN. Cell death in the pathogenesis of heart disease: mechanisms and significance. Annu Rev Physiol 2010; 72: 19-44.

60. Valentim L, Lawrence KM, Townsend PA, Carroll CJ, Soond S, Scarabelli TM et al. Urocortin inhibits Beclin1-mediated autophagic cell death in cardiac myocytes exposed to ischaemia/reperfusion injury. J Mol Cell Cardiol 2006; 40: 846-852.

cc)(i) (2) Cell Death and Disease is an open-access journal published by Nature Publishing Group. This work is licensed under a Creative Commons Attribution-NonCommercialShareAlike 3.0 Unported License. The images or other third party material in this article are included in the article's Creative Commons license, unless indicated otherwise in the credit line; if the material is not included under the Creative Commons license, users will need to obtain permission from the license holder to reproduce the material. To view a copy of this license, visit http://creativecommons.org/licenses/ by-nc-sa/3.0/

Supplementary Information accompanies this paper on Cell Death and Disease website (http://www.nature.com/cddis) 